DOI: $10.6060 / \mathrm{mhc} 140503 \mathrm{~s}$

\title{
Synthesis of 4,5-Dicyanophthalic Acid and Its Functional Derivatives
}

\author{
Ekaterina N. Shevchenko, ${ }^{@}$ Ludmila I. Solovyova, and Evgeny A. Lukyanets \\ Dedicated to Corresponding member of Russian Academy of Sciences O. I. Koifman \\ on the occasion of his $70^{\text {th }}$ birthday
}

Organic Intermediates and Dyes Institute, 123995 Moscow, Russia

${ }^{@}$ Corresponding author E-mail: gira_sol@list.ru

A new phthalogen - 4,5-dicyanophthalic acid - was prepared in a few simple steps starting from pyromellitic anhydride.

Keywords: 4,5-Dicyanophthalic acid, 4,5-dicyanophthalic acid functional derivatives, substituted phthalocyanines.

\section{Синтез 4,5-Аицианофталевой кислоты и её функциональных ПрОИЗВоАНЫХ}

\author{
Е. Н. Шевченко, ${ }^{@}$ ᄉ. И. Соловьёва, Е. А. Аукьянец \\ Посвящается член-корреспонденту РАН О. И. Койфману по случаю его 70-летнего юбилея
}

Институт органических полупродуктов и красителей, 123995 Москва, Россия

${ }^{\circledR}$ E-mail: gira_sol@list.ru

\begin{abstract}
Новый фталоген - 4,5-дищианофталевая кислота - была получена в несколько простых стадий из пиромеллитового ангидрида
\end{abstract}

Ключевые слова: 4,5-Дицианофталевая кислота, функциональные производные 4,5-дицианофталевой кислоты, замещенные фталоцианины.

\section{Introduction}

Phthalocyanines $(\mathrm{Pc})$ are currently ones of the most popular classes of organic dyes. They are used as catalysts of different reactions, ${ }^{[1,2]}$ materials for nonlinear optics ${ }^{[3]}$ and dye-sensitized solar cells,,$^{[4,5]}$ photosensitizers for photodynamic therapy of cancer ${ }^{[6,7]}$ and so on.

Diversity of applications of Pc requires their different physicochemical properties, which can be achieved mainly by changing the central atom or introduction of various substituents into the macrocycle ring. Introduction of peripheral substituents can increase the solubility of Pc in aqueous media or organic solvents, tunes their optical and redox properties or provides the ability to form supramolecular assemblies.

Pc substituted by carboxylic groups are of considerable interest due to solubility of their salts in aqueous media, which is important for medical applications such as photodynamic therapy. ${ }^{[8]}$ Carboxylic functions also provide flexible opportunities for obtaining various functional derivatives (esters, amides, imides), conjugates with natural or synthetic molecules. ${ }^{[9-12]}$ Asymmetric Pc containing one or two carboxylic groups are currently widely studied as components for dye-sensitized solar cells. ${ }^{[4,13,14]}$ Among different types of polycarboxy substituted Pc 2,3,9,10,16,17,23,24-octacarboxyphthalocyanine and its metal complexes are of 
particular interest because of its highly symmetric structure. For example, OCPcAl and OCPcZn sodium salts were used as photosensitizers for photodynamic therapy. ${ }^{[15,16]}$ OCPcCo sodium salt under the trade name Theraphthal ${ }^{\circledR}$ is currently under clinical trials for the catalytic cancer therapy. ${ }^{[1,17,18]}$ Sodium salts of OCPcCo and OCPcZn are also studied as sensitizers for sonodynamic cancer therapy. ${ }^{[19,20]}$

Sodium salts of OCPcM $(\mathrm{M}=\mathrm{Al}, \mathrm{Co}, \mathrm{Zn}, \mathrm{Fe})$ are precursors for the synthesis of covalent exocyclic conjugates with $\mathrm{Pt}^{\mathrm{II}}$. These conjugates combine properties of a photosensitizer for photodynamic therapy (or catalyst for catalytic cancer therapy) with cytotoxic properties of platinum(II) compounds which are widely used in cancer chemotherapy. ${ }^{[21-23]}$

OCPcM were first obtained by fusion of pyromellitic anhydride with urea in the presence of metal salts followed by hydrolysis of the imide groups ${ }^{[15,24,25]}$ (Figure 1). In this case oligomeric and polymeric Pc are also formed as by-products the removal of which requires laborious chromatographic purification. Yields of the target OCPcM usually do not exceed 5-30\% depending on the central metal. Only few examples of preparation of monomeric free ligand $\mathrm{OCPcH}_{2}$ starting from 1,2,4,5-tetracyanobenzene in mild conditions with moderate yields are reported. ${ }^{[26,27]}$

A much more attractive way which allows to obtain both metal complexes and free ligand and avoids formation of polymeric by-products is the tetramerization of 4,5-dicyanophthalic acid derivatives, mainly its alkyl esters ${ }^{[28-31]}$ followed by hydrolysis if the acids are target compounds. Only a few reports on the synthesis of $N$-unsubstituted imide $^{[32,33]}$ and $N, N$-dialkylamides ${ }^{[33,34]}$ of 4,5-dicyanophthalic acid were found in the literature.

The known approach to the synthesis of 4,5-dicyanophthalic acid derivatives is based on bromination of orthoxylene to produce 1,2-dibromo-4,5-dimethylbenzene followed by oxidation of methyl groups with potassium permanganate, derivatization of carboxyl groups and finally replacing bromine atoms by cyano groups by Rosenmund-von Braun reaction. The drawbacks of this method are low yields (10-15\%) and the necessity to work with toxic reagents and heavy metals (bromine, potassium permanganate, copper cyanide).$^{[28,30,33]}$ Synthesis of 4,5-dicyanophthalic acid itself has not been described yet although it can simplify and expand the scope of preparation of its derivatives
In this paper we report a method for preparation of 4,5-dicyanophthalic acid in a few simple steps from available starting material - pyromellitic acid or its anhydride as well as procedures for synthesis of the whole range of its functional derivatives including previously poorly described $N, N$-disubstituted diamides.

\section{Experimental}

The reagents and solvents of HPLC grade were purchased from Sigma-Aldrich, Merck, Fluka or Alfa Aesar and used as received, unless otherwise noted. ${ }^{1} \mathrm{H}$ NMR spectra were run on Bruker AM 300 spectrometer with internal standard $\mathrm{Me}_{4} \mathrm{Si}$. Mass spectra were obtained under GC/MS conditions on Varian 3800 GC instrument with Varian 2200 ion trap mass spectrometer (EI $70 \mathrm{eV}$ ). IR spectra were recorded with Monitoring 1201 FT-IR spectrometer (KBr tablets). Elemental analyses were carried out on a Vario Micro Cube CHN Analyzer. Electronic absorption spectra were recorded with Hewlett Packard 8453 spectrophotometer.

4,5-Dicarboxyphthalimide (5). Pyromellitic anhydride 1 (17.2 g, $78.7 \mathrm{mmol})$ was heated in distilled water $(400 \mathrm{ml})$ until the precipitate dissolved. Under stirring $25 \%$ aqueous ammonia ( $4.7 \mathrm{ml}, 63.0 \mathrm{mmol}$ ) was added dropwise to the resulting solution of pyromellitic acid 2 at $30-35{ }^{\circ}$ C. Stirring was continued for 1-2 hours, then the solvent was evaporated under reduced pressure and the resulting solid mixture of ammonium salts of pyromellitic acid was heated at $260-270{ }^{\circ} \mathrm{C}$ for one hour. The resulting solid was crystallized from water. Pyromellitic diimide (1.3 g, $8 \%$ ) was separated by hot filtration, the filter cake was washed with a small amount of hot water. The crystals of the product precipitated from the filtrate on cooling, which were filtered off and dried in a vacuum desiccator over calcium chloride to yield $8.8 \mathrm{~g} \mathrm{(48 \% )}$ of imide $\mathbf{5}$ as white solid. M.p. $278-279^{\circ} \mathrm{C}$. Anal. calcd. for $\mathrm{C}_{10} \mathrm{H}_{5} \mathrm{NO}_{6}$ : C, 51.08; H, 2.14; N, 5.96. Found: C, 50.89; H, 2.21; $\mathrm{N}, 5.90$. IR $(\mathrm{KBr}) \vee \mathrm{cm}^{-1}: 3458,3217,3065,1782,1732,1705 .{ }^{1} \mathrm{H}$ NMR (DMSO- $\left.d_{6}\right) \delta_{\mathrm{H}}$ ppm: $11.64(1 \mathrm{H}, \mathrm{s}, \mathrm{NH}), 7.98(2 \mathrm{H}, \mathrm{s}, \mathrm{Ar} H)$. Unreacted pyromellitic acid 2 (8.1 g, $41 \%)$ was recovered after evaporation of the filtrate. The purity of the product and recovered acid 2 can be controlled by TLC of its ethyl esters prepared by heating the sample of analyzed material with ethyl orthoformate at $150-160{ }^{\circ} \mathrm{C}$ for $20-30 \mathrm{~min}$.

4,5-Dicarbamoylphthalic acid ammonium salt (6). Finely powdered imide 5 ( $8.8 \mathrm{~g}, 37.5 \mathrm{mmol}$ ) was added to $25 \%$ aqueous ammonia $(100 \mathrm{ml})$ with vigorous stirring. After $10 \mathrm{~h}$ ammonia was evaporated under reduced pressure at room temperature. The product was precipitated with acetone from aqueous solution, filtered off and dried in air and then in a vacuum desiccator over calcium chloride to yield $10.7 \mathrm{~g}(100 \%)$ of ammonium salt $\mathbf{6}$ as<smiles>O=c1oc(=O)c2cc3c(=O)oc(=O)c3cc12</smiles><smiles>N#Cc1cc(C#N)c(C#N)cc1C#N</smiles>
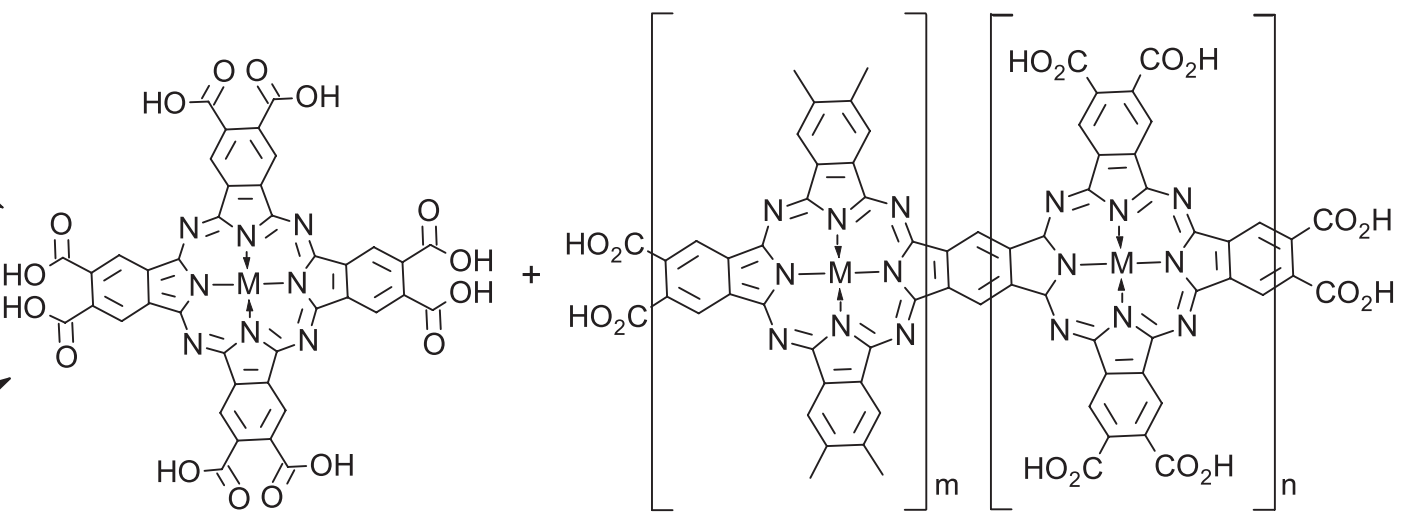

Figure 1. Formation of oligomeric and polymeric Pc along with monomeric OCPcM from pyromellitic anhydride or 1,2,4,5-tetracyanobenzene. 
white solid. IR $(\mathrm{KBr}) \vee \mathrm{cm}^{-1}: 3595,1690,1610,1567,1493,1438$, 1400, 1375, 1329. ${ }^{1} \mathrm{H}$ NMR $\left(\mathrm{D}_{2} \mathrm{O}\right) \delta_{\mathrm{H}} \mathrm{ppm}: 7.59(2 \mathrm{H}, \mathrm{s}, \operatorname{Ar} H)$.

4,5-Dicyanophthalic acid (solvate with DMF 1:1) (7). Ammonium salt 6 (10.7 g, $37.5 \mathrm{mmol})$ was added to dry DMF $(45 \mathrm{ml})$ and resulting suspension was stirred for 10-15 min. until a homogeneous slurry formed. Then the reaction mixture was cooled to $-5{ }^{\circ} \mathrm{C}$ and phosphorus oxychloride $(10.9 \mathrm{ml}, 117.0 \mathrm{mmol})$ was added dropwise at $-5-0{ }^{\circ} \mathrm{C}$ followed by stirring at room temperature for 1 hour and at $35-40{ }^{\circ} \mathrm{C}$ for $30 \mathrm{~min}$. Then resulting suspension was poured into mixture of crushed ice and ethyl acetate with stirring. The organic layer was separated and aqueous layer was extracted with ethyl acetate twice. The combined organic extracts were dried over magnesium sulfate. The residue after evaporation of the solvent was stirred with toluene for 1 hour, the precipitate was filtered off and dried in air and then in a vacuum desiccator over calcium chloride to yield $7.8 \mathrm{~g} \mathrm{(72 \% )} \mathrm{of} \mathrm{acid} 7$ as white solid. Anal. calcd. for $\mathrm{C}_{10} \mathrm{H}_{4} \mathrm{~N}_{2} \mathrm{O}_{4} \cdot \mathrm{C}_{3} \mathrm{H}_{7} \mathrm{NO}: \mathrm{C}, 53.98 ; \mathrm{H}, 3.83 ; \mathrm{N}, 14.53$. Found: C, 53.98; H, 3.37; N, 13.95. IR (KBr) $v \mathrm{~cm}^{-1}$ : 3116, 3052, $2938,2243,1933,1853,1737,1720,1633 .{ }^{1} \mathrm{H}$ NMR (DMSO- $\left.d_{6}\right) \delta_{\mathrm{H}}$ ppm: $8.45(2 \mathrm{H}, \mathrm{s}, \mathrm{ArH}), 7.94\left(1 \mathrm{H}, \mathrm{s}, \mathrm{HCON}\left(\mathrm{CH}_{3}\right)_{2}\right), 2.90(3 \mathrm{H}, \mathrm{s}$, $\left.\mathrm{HCON}\left(\mathrm{CH}_{3}\right)_{2}\right), 2.74\left(3 \mathrm{H}, \mathrm{s}, \mathrm{HCON}\left(\mathrm{CH}_{3}\right)_{2}\right)$.

In some cases 4,5-dicyanophthalic acid 7 was isolated as a mixture with its anhydride 10. In this case the anhydride $\mathbf{1 0}$ can be hydrolyzed under mild conditions by treatment with water at room temperature until complete dissolution of the precipitate (2-3 minutes), followed by extraction of acid 7 with ethyl acetate. The product purified in this manner does not contain DMF. Anal. calcd. for $\mathrm{C}_{10} \mathrm{H}_{4} \mathrm{~N}_{2} \mathrm{O}_{4}$ : C, 55.57; H, 1.87; N, 12.96. Found: C, 55.90; H, 2.17; N, 12.92. IR (KBr) $v \mathrm{~cm}^{-1}: 3115,3053,2243,1741,1717 .{ }^{1} \mathrm{H}$ NMR (DMSO- $\left.d_{6}\right) \delta_{\mathrm{H}}$ ppm: $8.44(2 \mathrm{H}, \mathrm{s}, \mathrm{Ar} H)$.

We used acid 7 as solvate with DMF for preparation of all its functional derivatives.

\section{Preparation of Phthalonitriles 11-20}

4,5-Bis(N,N-diethylcarbamoyl)phthalonitrile (11). Under stirring oxalyl chloride $(0.5 \mathrm{ml}, 5.8 \mathrm{mmol})$ and catalytic amount of DMF were added to a suspension of compound $7(0.5 \mathrm{~g}, 1.7 \mathrm{mmol})$ in $25 \mathrm{ml}$ of dry DCM. Stirring was continued for $10-12 \mathrm{~h}$, the solvent and excess of oxalyl chloride were removed in vacuum. The residue was dissolved in $10 \mathrm{ml}$ of dry DCM, diethylamine $(0.9 \mathrm{ml}, 9.0$ $\mathrm{mmol}$ ) was added to resulting solution with vigorous stirring. After $2 \mathrm{~h}$ the solvent was evaporated and the crude product was purified by column chromatography on $\mathrm{SiO}_{2}$ (eluent - chloroform/ethanol, $100: 1)$ to yield $0.36 \mathrm{~g}(64 \%)$ of phthalonitrile $\mathbf{1 1}$ as white solid. M.p. $192-194{ }^{\circ} \mathrm{C}$. (lit. $\left.191-192{ }^{\circ} \mathrm{C}^{[33]}\right)$. Anal. calcd. for $\mathrm{C}_{18} \mathrm{H}_{22} \mathrm{~N}_{4} \mathrm{O}_{2}$ : C, 66.24; H, 6.79; N, 17.17. Found: C, 66.44; H, 7.00; N, 16.72. IR $(\mathrm{KBr}) \vee \mathrm{cm}^{-1}: 3112,3037,2973,2936,2874,2851,2233,1642 .{ }^{1} \mathrm{H}$ $\operatorname{NMR}\left(\mathrm{CDCl}_{3}\right) \delta_{\mathrm{H}}$ ppm: $7.70(2 \mathrm{H}, \mathrm{s}, \mathrm{Ar} H), 3.50(4 \mathrm{H}, \mathrm{q}, J=7.4 \mathrm{~Hz}$, $\left.\mathrm{CH}_{2}\right), 3.19\left(4 \mathrm{H}, \mathrm{q}, J=7.0 \mathrm{~Hz}, \mathrm{CH}_{2}\right), 1.21\left(6 \mathrm{H}, \mathrm{t}, J=7.1 \mathrm{~Hz}, \mathrm{CH}_{3}\right)$, $1.14\left(6 \mathrm{H}, \mathrm{t}, J=7.2 \mathrm{~Hz}, \mathrm{CH}_{3}\right)$.

4,5-Bis $(N, N$-dibutylcarbamoyl)phthalonitrile (12). Prepared similarly to phthalonitrile $\mathbf{1 1}$ from compound 7 (0.5 g, 1.7 $\mathrm{mmol})$ and dibutylamine $(1.5 \mathrm{ml}, 9.0 \mathrm{mmol})$. Yield $0.47 \mathrm{~g}(60 \%)$; white solid with m.p. $100-103{ }^{\circ} \mathrm{C}$. Anal. calcd. for $\mathrm{C}_{26} \mathrm{H}_{38} \mathrm{~N}_{4} \mathrm{O}_{2}$ : C, 71.20; H, 8.73; N, 12.77. Found: C, 71.03; H, 8.85; N, 12.73. IR $(\mathrm{KBr}) \vee \mathrm{cm}^{-1}: 3109,3060,3027,2962,2934,2874,2234,1644 .{ }^{1} \mathrm{H}$ NMR $\left(\mathrm{CDCl}_{3}\right) \delta_{\mathrm{H}}$ ppm: 7,68 (2H, s, ArH), $3.42(4 \mathrm{H}, \mathrm{t}, J=7.5 \mathrm{~Hz}$, $\left.\mathrm{NCH}_{2}\right), 3.08\left(4 \mathrm{H}, \mathrm{t}, J=7.5 \mathrm{~Hz}, \mathrm{NCH}_{2}\right), 1.67-1.45(8 \mathrm{H}, \mathrm{m}, \mathrm{CH})$, 1.37 (4H, sextet, $\left.J=7.2 \mathrm{~Hz}, \mathrm{CH}_{2} \mathrm{CH}_{3}\right), 1.18$ (4H, sextet, $J=7.2$ $\left.\mathrm{Hz}, \mathrm{CH}_{2} \mathrm{CH}_{3}\right), 0.97\left(6 \mathrm{H}, \mathrm{t}, J=7.5 \mathrm{~Hz}, \mathrm{CH}_{3}\right), 0.84(6 \mathrm{H}, \mathrm{t}, J=7.5$ $\mathrm{Hz}, \mathrm{CH}_{3}$ ).

4,5-Bis(1-piperidinylcarbonyl)phthalonitrile (13). Prepared similarly to phthalonitrile $\mathbf{1 1}$ from compound $7(0.5 \mathrm{~g}, 1.7 \mathrm{mmol})$ and piperidine $(0.9 \mathrm{ml}, 9.1 \mathrm{mmol})$. Yield $0.36 \mathrm{~g}(59 \%)$; white solid with m.p. $210-213{ }^{\circ} \mathrm{C}$. Anal. calcd. for $\mathrm{C}_{20} \mathrm{H}_{22} \mathrm{~N}_{4} \mathrm{O}_{2}: \mathrm{C}, 68.55 ; \mathrm{H}$, 6.33; N, 15.99. Found: C, 68.07; H, 6.21; N, 15.56. IR (KBr) v $\mathrm{cm}^{-1}: 3023,3000,2941,2867,2236,1637 .{ }^{1} \mathrm{H} \mathrm{NMR}\left(\mathrm{CDCl}_{3}\right) \delta_{\mathrm{H}}$ ppm: $7.71(2 \mathrm{H}, \mathrm{s}, \mathrm{Ar} H), 3.65\left(4 \mathrm{H}\right.$, broad s, $\left.\mathrm{NCH}_{2}\right), 3.21(4 \mathrm{H}, \mathrm{t}, J=$ $\left.4.5 \mathrm{~Hz}, \mathrm{NCH}_{2}\right), 1.80-1.50\left(12 \mathrm{H}, \mathrm{m}, \mathrm{CH}_{2}\right)$.

4,5-Bis[(4-methyl-1-piperazinyl) carbonyl]phthalonitrile (14). Under stirring oxalyl chloride $(0.5 \mathrm{ml}, 5.8 \mathrm{mmol})$ and catalytic amount of DMF were added to a suspension of compound 7 (0.5 g, $1.7 \mathrm{mmol}$ ) in $25 \mathrm{ml}$ of dry DCM. Stirring was continued for 10-12 $\mathrm{h}$, the solvent and excess of oxalyl chloride were removed in vacuum. The residue was dissolved in $10 \mathrm{ml}$ of dry DCM, 1-methylpiperazine $(1.0 \mathrm{ml}, 9.0 \mathrm{mmol})$ was added to resulting solution with vigorous stirring. After $2 \mathrm{~h}$ the reaction mixture was washed with $2.5 \%$ solution of $\mathrm{Na}_{2} \mathrm{CO}_{3}$ and then with brine, the solvent was evaporated and the residue was crystallized from toluene to yield $0.37 \mathrm{~g} \mathrm{(55 \% )} \mathrm{of} \mathrm{compound} \mathbf{1 4}$ as white solid. M.p. 280-282 ${ }^{\circ} \mathrm{C}$ (dec.). Anal. calcd. for $\mathrm{C}_{20} \mathrm{H}_{24} \mathrm{~N}_{6} \mathrm{O}_{2}$ : C, 63.14; $\mathrm{H}, 6.36$; $\mathrm{N}, 22.09$. Found: C, 63.46; H, 6.18; N, 21.87. IR (KBr) $v \mathrm{~cm}^{-1}: 2977$, 2946, 2849, 2799, 2234, 1641. 'H NMR $\left(\mathrm{CDCl}_{3}\right) \delta_{\mathrm{H}} \mathrm{ppm}: 7.74(2 \mathrm{H}$, s, $\mathrm{ArH}), 3.78\left(4 \mathrm{H}\right.$, broad s, $\left.\mathrm{CH}_{2}\right), 3.31\left(4 \mathrm{H}\right.$, broad s, $\left.\mathrm{CH}_{2}\right), 2.6-2.4$ $\left(8 \mathrm{H}, \mathrm{m}, \mathrm{CH}_{2}\right),\left(6 \mathrm{H}, \mathrm{s}, \mathrm{CH}_{3}\right)$.

4,5-Bis(heptyloxycarbonyl)phthalonitrile (15). N,N'-Dicyclohexylcarbodiimide $(0.18 \mathrm{~g}, 0.87 \mathrm{mmol})$ and 1-heptanol $(0.12$ $\mathrm{ml}, 0.85 \mathrm{mmol})$ were added to suspension of compound $7(0.10 \mathrm{~g}$, $0.35 \mathrm{mmol}$ ) in $1 \mathrm{ml}$ of dry DCM with stirring at $0{ }^{\circ} \mathrm{C}$. The reaction mixture was kept at $0{ }^{\circ} \mathrm{C}$ for $2 \mathrm{~h}$ and at room temperature overnight. Then the reaction mixture was filtered off and precipitate was washed with DCM, filtrates were combined and evaporated. The residue was purified by column chromatography on $\mathrm{SiO}_{2}$ (eluent chloroform) to yield $0.14 \mathrm{~g}$ (71\%) of compound $\mathbf{1 5}$ as white solid. M.p. $45-47^{\circ} \mathrm{C}$. Anal. calcd. for $\mathrm{C}_{24} \mathrm{H}_{32} \mathrm{~N}_{2} \mathrm{O}_{4}$ : C, 69.88; H, 7.82; $\mathrm{N}$, 6.79. Found: C, 70.01; H, 7.85; N, 6.82. GC/MS: $m / z 413.6$ $[\mathrm{M}+\mathrm{H}]^{+}$. Calcd. for $\mathrm{C}_{24} \mathrm{H}_{32} \mathrm{~N}_{2} \mathrm{O}_{4}$ 412.5. IR $(\mathrm{KBr}) v \mathrm{~cm}^{-1}: 3116,3053$, 2956, 2926, 2870, 2852, 2238, 1726, 1714. ${ }^{1} \mathrm{H} \mathrm{NMR}\left(\mathrm{CDCl}_{3}\right) \delta_{\mathrm{H}}$ ppm: $8.13(2 \mathrm{H}, \mathrm{s}, \mathrm{Ar} H), 4.36\left(4 \mathrm{H}, \mathrm{t}, J=7.0 \mathrm{~Hz}, \mathrm{OCH}_{2}\right), 1.76(4 \mathrm{H}$, $\left.\mathrm{m}, J=7.0 \mathrm{~Hz}, \mathrm{OCH}_{2} \mathrm{CH}_{2}\right), 1.5-1.2\left(16 \mathrm{H}, \mathrm{m}, \mathrm{CH}_{2}\right), 0.90(6 \mathrm{H}, \mathrm{t}, J=$ 6.8, $\mathrm{CH}_{3}$ ).

4,5-Bis(tert-butoxycarbonyl)phthalonitrile (16). Under stirring oxalyl chloride $(0.5 \mathrm{ml}, 5.8 \mathrm{mmol})$ and catalytic amount of DMF were added to a suspension of compound 7 (0.5 g, 1.7 $\mathrm{mmol}$ ) in $25 \mathrm{ml}$ of dry DCM. Stirring was continued for 10-12 h, the solvent and excess of oxalyl chloride were removed in vacuum. The residue was dissolved in $10 \mathrm{ml}$ of dry DCM, pyridine $(1.0$ $\mathrm{ml}, 12.4 \mathrm{mmol}$ ) was added to resulting solution with vigorous stirring followed by dry tert-butanol $(2.0 \mathrm{~g}, 27.0 \mathrm{mmol})$. After 2 $\mathrm{h}$ the solvent was evaporated, the residue was purified by column chromatography on $\mathrm{SiO}_{2}$ (eluent - DCM/acetone, 30:1) to yield $0.32 \mathrm{~g}(56 \%)$ of compound $\mathbf{1 6}$ as white solid. M.p. $160-162{ }^{\circ} \mathrm{C}$. Anal. calcd. for $\mathrm{C}_{18} \mathrm{H}_{20} \mathrm{~N}_{2} \mathrm{O}_{4}$ : C, 65.84; $\mathrm{H}, 6.14 ; \mathrm{N}, 8.53$. Found: $\mathrm{C}$, 65.99; H, 5.96; N, 8.67. IR (KBr) $v \mathrm{~cm}^{-1}: 3119,3090,3058,2988$, 2937, 2235, 1725. ${ }^{1} \mathrm{H}$ NMR $\left(\mathrm{CDCl}_{3}\right) \delta_{\mathrm{H}} \mathrm{ppm}: 8.03(2 \mathrm{H}, \mathrm{s}, \mathrm{Ar} H)$, $1.61\left(18 \mathrm{H}, \mathrm{s}, \mathrm{CH}_{3}\right)$.

4,5-Dis(2-(N,N-dimethylaminoethoxycarbonyl)phthalonitrile (17). Prepared similarly to phthalonitrile 14 from compound 7 (0.5 $\mathrm{g}, 1.7 \mathrm{mmol})$ and 2-dimethylaminoethanol $(0.5 \mathrm{ml}, 5.0 \mathrm{mmol})$. The crude product was purified by column chromatography on $\mathrm{Al}_{2} \mathrm{O}_{3}$ (eluent - DCM) to yield $0.36 \mathrm{~g}(58 \%)$ of compound $\mathbf{1 7}$ as white solid. M.p. $86-87^{\circ} \mathrm{C}$. Anal. calcd. for $\mathrm{C}_{18} \mathrm{H}_{22} \mathrm{~N}_{4} \mathrm{O}_{4}: \mathrm{C}, 60.32 ; \mathrm{H}, 6.19$; $\mathrm{N}, 15.63$. Found: C, 60.21; H, 6.17; N, 15.18. ${ }^{1} \mathrm{H}$ NMR $\left(\mathrm{CDCl}_{3}\right) \delta_{\mathrm{H}}$ ppm: $8.16(2 \mathrm{H}, \mathrm{s}, \mathrm{Ar} H), 4.5\left(4 \mathrm{H}, \mathrm{t}, J=5.6 \mathrm{~Hz}, \mathrm{OCH}_{2}\right), 2.74(4 \mathrm{H}, \mathrm{t}$, $\left.J=5.6 \mathrm{~Hz}, \mathrm{CH}_{2}\right), 2.35\left(12 \mathrm{H}, \mathrm{s}, \mathrm{CH}_{3}\right)$.

4,5-Dicyanophthalic acid anhydride (10). The mixture of compound $7(0.5 \mathrm{~g}, 1.7 \mathrm{mmol})$ and acetyl chloride $(4 \mathrm{ml})$ was refluxed for $3 \mathrm{~h}$. Then acetyl chloride was evaporated, the residue was treated with toluene. The precipitate was filtered off, washed with cold toluene and dried in a vacuum desiccator over calcium chloride to yield $0.32 \mathrm{~g}(95 \%)$ of compound $\mathbf{1 0}$ as white solid. IR $(\mathrm{KBr}) \vee \mathrm{cm}^{-1}: 3118,3056,2244,1864,1756$.

4,5-Dicyano- $N$-nonylphthalimide (18). The mixture of anhydride $10(0.10 \mathrm{~g}, 0.51 \mathrm{mmol})$, 1-nonylamine $(0.11 \mathrm{ml}, 0.61$ $\mathrm{mmol}$ ) and acetic acid $(1 \mathrm{ml})$ with one drop of pyridine was refluxed 
for $1 \mathrm{~h}$. Then the reaction mixture was concentrated in vacuum and the residue was purified by column chromatography on $\mathrm{SiO}_{2}$ (eluent - DCM) to yield $0.11 \mathrm{~g}(68 \%)$ of compound 18 as white solid. M.p. 78-80 ${ }^{\circ} \mathrm{C}$. Anal. calcd. for $\mathrm{C}_{19} \mathrm{H}_{21} \mathrm{~N}_{3} \mathrm{O}_{2}$ : C, $70.57 ; \mathrm{H}, 6.55 ; \mathrm{N}, 12.99$. Found: C, 70.80; H, 6.63; N, 12.94. GC/MS: $m / z 323.5[\mathrm{M}]^{+}$. Calcd. for $\mathrm{C}_{19} \mathrm{H}_{21} \mathrm{~N}_{3} \mathrm{O}_{2}$ 323.4. IR (KBr) $v \mathrm{~cm}^{-1}: 3275,3113,3050,2955$, 2926, 2856, 2238, 1779, 1710. ${ }^{1} \mathrm{H}$ NMR $\left(\mathrm{CDCl}_{3}\right) \delta_{\mathrm{H}} \mathrm{ppm}: 8.27(2 \mathrm{H}$, s, $\mathrm{Ar} H), 3,75\left(2 \mathrm{H}, \mathrm{t}, J=7.4 \mathrm{~Hz}, \mathrm{NCH}_{2}\right), 1.70\left(2 \mathrm{H}, \mathrm{m}, \mathrm{CH}_{2}\right), 1.4-1.2$ $\left(12 \mathrm{H}, \mathrm{m}, \mathrm{CH}_{2}\right), 0.88\left(3 \mathrm{H}, \mathrm{t}, J=6.8 \mathrm{~Hz}, \mathrm{CH}_{3}\right)$.

4,5-Dicyano-N-(ethoxycarbonyl)methylphthalimide (19). Prepared similarly to phthalonitrile 18 from compound $10(0.10$ g, $0.51 \mathrm{mmol})$ and glycine ethyl ester hydrochloride $(0.08 \mathrm{~g}, 0.61$ mmol). Yield $0.07 \mathrm{~g} \mathrm{(48 \% );} \mathrm{white} \mathrm{solid} \mathrm{with} \mathrm{m.p.} 174-176^{\circ} \mathrm{C}$. Anal. calcd. for $\mathrm{C}_{14} \mathrm{H}_{9} \mathrm{~N}_{3} \mathrm{O}_{4}$ : C, 59.37; H, 3.20; N, 14.84. Found: C, 59.48; H, 3.25; N, 14.66. GC/MS: $m / z 284.3[\mathrm{M}+\mathrm{H}]^{+}$. Calcd. for $\mathrm{C}_{14} \mathrm{H}_{9} \mathrm{~N}_{3} \mathrm{O}_{4}$ 283.2. IR (KBr) $v \mathrm{~cm}^{-1}: 3110,3050,2994,2956,2240$, $1790,1728 .{ }^{1} \mathrm{H}$ NMR $\left(\mathrm{CDCl}_{3}\right) \delta_{\mathrm{H}} \mathrm{ppm}: 8.32(2 \mathrm{H}, \mathrm{s}, \mathrm{Ar} H), 4.50(2 \mathrm{H}$, $\left.\mathrm{s}, \mathrm{NCH}_{2}\right), 4.26\left(2 \mathrm{H}, \mathrm{q}, J=7.0 \mathrm{~Hz}, \mathrm{OCH}_{2}\right), 1.31(3 \mathrm{H}, \mathrm{t}, J=7.5 \mathrm{~Hz}$, $\mathrm{CH}_{3}$ ).

4,5-Dicyano- $N$-(3-picolyl)phthalimide (20). Prepared similarly to phthalonitrile $\mathbf{1 8}$ from compound $\mathbf{1 0}(0.10 \mathrm{~g}, 0.51 \mathrm{mmol})$ and 3-picolylamine $(0.06 \mathrm{ml}, 0.60 \mathrm{mmol})$. The crude residue was purified by column chromatography on $\mathrm{SiO}_{2}$ (eluent - chloroform/ acetone, 5:1) to yield $0.08 \mathrm{~g}(57 \%)$ of compound $\mathbf{2 0}$ as white solid. M.p. $250-253{ }^{\circ} \mathrm{C}$ (dec.). Anal. calcd. for $\mathrm{C}_{16} \mathrm{H}_{8} \mathrm{~N}_{4} \mathrm{O}_{2}$ : C, 66.67; $\mathrm{H}$, $2.80 ; \mathrm{N}, 19.44$. Found: $\mathrm{C}, 66.47 ; \mathrm{H}, 2.87 ; \mathrm{N}, 18.84$. IR $(\mathrm{KBr}) \vee \mathrm{cm}^{-1}$ : 3122, 3057, 2937, 2241, 1788, 1758, 1718. ${ }^{1} \mathrm{H}$ NMR (DMSO- $d_{6}$ ) $\delta_{\mathrm{H}}$ ppm: $8.74(2 \mathrm{H}, \mathrm{s}, \operatorname{Ar} H), 8.60(1 \mathrm{H}, \mathrm{s}, \operatorname{Ar} H), 8.50(1 \mathrm{H}, \mathrm{d}, J=4.7$ $\mathrm{Hz}, \operatorname{Ar} H), 7.76(1 \mathrm{H}, \mathrm{d}, J=8.1 \mathrm{~Hz}, \operatorname{Ar} H), 7.36(1 \mathrm{H}, \mathrm{m}, \operatorname{Ar} H), 4.85$ $\left(2 \mathrm{H}, \mathrm{s}, \mathrm{CH}_{2}\right)$.

\section{Preparation of Phthalocyanines 21, 22}

2,3,9,10,16,17,23,24-Octakis(N,N-dibutylaminocarbamoyl)phthalocyanatozinc(II) (21). The mixture of phthalonitrile $12(0.30 \mathrm{~g}$, $0.68 \mathrm{mmol}), \mathrm{Zn}(\mathrm{OAc})$, $(0.04 \mathrm{~g}, 0.22 \mathrm{mmol}), 1,8$-diazabicyclo[5.4.0] undec-7-ene $(0.05 \mathrm{~g}, 0.34 \mathrm{mmol})$ and dry diglyme $(1.5 \mathrm{ml})$ was refluxed for $4 \mathrm{~h}$ under argon atmosphere. After cooling the reaction mixture to room temperature the solvent was evaporated under reduced pressure, and the residue was chromatographed on $\mathrm{SiO}_{2}$ (eluent - chloroform/acetone, 30:1), then on $\mathrm{Al}_{2} \mathrm{O}_{3}$ (eluent - chloroform/ acetone, $30: 1)$ to yield $0.14 \mathrm{~g}$ (45\%) of complex 21 as dark blue solid. UV-Vis (ethanol) $\lambda_{\text {max }} \mathrm{nm}(\lg \varepsilon): 676$ (5.53), 610 (4.68), 352 (4.99); (DCM with $0.04 \% \mathrm{Et}_{3} \mathrm{~N}$ ): 681 (5.49), 614 (4.66), 353 (4.93). Anal. calcd. for $\mathrm{C}_{104} \mathrm{H}_{152} \mathrm{~N}_{16}^{3} \mathrm{O}_{8} \mathrm{Zn}$ : C, 68.64; $\mathrm{H}$, $8.41 ; \mathrm{N}, 12.23$. Found: C, 68.50; H, 8.49; N, 12.12. IR (KBr) $v \mathrm{~cm}^{-1}$ : $3451,2958,2932,2871,1640,1590$.

2,3,9,10,16,17,23,24-Octakis(heptoxycarbonyl)phthalocyanatozinc(II) (22). The mixture of phthalonitrile $15(0.10 \mathrm{~g}$, $0.24 \mathrm{mmol})$ and $\mathrm{Zn}(\mathrm{OAc})_{2}(0.013 \mathrm{~g}, 0.071 \mathrm{mmol})$ was heated at $185-190{ }^{\circ} \mathrm{C}$ for $3 \mathrm{~h}$ under argon atmosphere. After cooling to room temperature the reaction mixture was treated with ethanol, filtered and dried. The crude product was chromatographed on $\mathrm{Al}_{2} \mathrm{O}_{3}$ (eluent - chloroform/ethanol, 30:1) to yield $0.52 \mathrm{~g}(51 \%)$ of complex 22 as dark blue solid. UV-Vis (DCM with $\left.0.04 \% \mathrm{Et}_{3} \mathrm{~N}\right) \lambda \mathrm{nm}(\lg \varepsilon): 686$ (5.42), 616 (4.72), 351 (4.91). Anal. calcd. for $\mathrm{C}_{96} \mathrm{H}_{128} \mathrm{~N}_{8} \mathrm{O}_{16} \mathrm{Zn:} \mathrm{C}$, $67.21 ; \mathrm{H}, 7.52 ; \mathrm{N}, 6.53$. Found: C, 67.01; H, 7.83; N, 6.41. IR (KBr) $v \mathrm{~cm}^{-1}: 3451,2957,2927,2871,2856,1726$.

Preparation of 4,5-Bis(alkoxycarbonyl)phthalonitriles from Tetraalkyl Pyromellitates (Scheme 1)

Preparation of Tetraalkyl Pyromellitates. Tetramethyl and tetrapropyl pyromellitates were synthesized with quantitative yield from dianhydride $\mathbf{1}$ and corresponding trialkyl orthoformates according to ${ }^{[31,35]}$

Tetramethyl pyromellitate. White solid with m.p. $146-147^{\circ} \mathrm{C}$. Anal. calcd. for $\mathrm{C}_{14} \mathrm{H}_{14} \mathrm{O}_{8}$ : C, 54.20; H, 4.55. Found: C, 54.34; H,
4.49. GC/MS: $m / z 279\left[\mathrm{M}-\mathrm{CH}_{3} \mathrm{O}\right]^{+}$. IR $(\mathrm{KBr}) \vee \mathrm{cm}^{-1}: 3124,3071$, 3006, 2959, 2855, 1735, 1724 .

Tetrapropyl pyromellitate. Colorless oil. Anal. calcd. for $\mathrm{C}_{22} \mathrm{H}_{30} \mathrm{O}_{8}: \mathrm{C}, 62.55 ; \mathrm{H}, 7.16$. Found: $\mathrm{C} 62.48, \mathrm{H}$ 7.02. GC/MS: $\mathrm{m} / z$ $423[\mathrm{M}+\mathrm{H}]^{+}$. IR $(\mathrm{KBr}) \vee \mathrm{cm}^{-1}: 2970,2941,2897,2881,1731$.

Tetrahexyl pyromellitate. Dianhydride $1(5.0 \mathrm{~g}, 22.9 \mathrm{mmol})$, $p$-toluenesulfonic acid $(0.4 \mathrm{~g}, 2.1 \mathrm{mmol})$, hexyl alcohol $(25 \mathrm{ml})$ and toluene $(50 \mathrm{ml})$ were reflux with Dean-Stark trap for $20 \mathrm{~h}$. Then the solvent was evaporated under reduced pressure and the residue was chromatographed on $\mathrm{Al}_{2} \mathrm{O}_{3}$ (eluent - hexane) to yield $9.5 \mathrm{~g} \mathrm{(70 \% )}$ of the product as colorless oil. Anal. calcd. for $\mathrm{C}_{34} \mathrm{H}_{54} \mathrm{O}_{8}: \mathrm{C}, 69.12$; H, 9.21. Found: C 69.35, H 9.11. GC/MS: $m / z 591[\mathrm{M}+\mathrm{H}]^{+}$. IR (KBr) $v \mathrm{~cm}^{-1}: 2957,2931,2872,2858,1735$.

2,4,5-Tripropyl pyromellitate. Tetrapropyl pyromellitate was hydrolyzed according to the reported procedure ${ }^{[35]}$ using propyl alcohol as the solvent to yield $94 \%$ of the product as colorless oil.

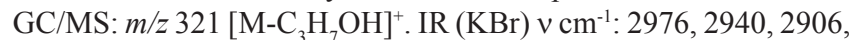
2877, 1734, 1715 .

2,4,5-Trimethyl pyromellitate. A stirred solution of tetramethyl pyromellitate $(2.00 \mathrm{~g}, 6.45 \mathrm{mmol})$ in THF $(20 \mathrm{ml})$ and $\mathrm{MeOH}(5 \mathrm{ml})$ was treated dropwise with a solution of $\mathrm{NaOH}(0.23 \mathrm{~g}, 5.75 \mathrm{mmol})$ in water $(3 \mathrm{ml})$ within $1.5 \mathrm{~h}$. Stirring was continued for $2 \mathrm{~h}$ followed by evaporation of the solvent. Then water $(20 \mathrm{ml})$ was added to the reaction mixture and unreacted tetramethyl pyromellitate $(0.62$ $\mathrm{g}, 2.00 \mathrm{mmol})$ was filtered off. The filtrate was acidified with concentrated $\mathrm{HCl}(0.5 \mathrm{ml})$ followed by extraction of the product with $\mathrm{Et}_{2} \mathrm{O}$ and evaporation of the solvent to yield $1.30 \mathrm{~g}(98 \%)$ of the product as white solid. GC/MS: $m / z 233\left[\mathrm{M}-\mathrm{CH}_{3} \mathrm{OH}, \mathrm{CH}_{3} \mathrm{O}\right]^{+}$. IR (KBr) $v \mathrm{~cm}^{-1}: 3051,2958,1730,1714$.

2,4,5-Trihexyl pyromellitate. A stirred solution of tetrahexyl pyromellitate $(2.00 \mathrm{~g}, 3.38 \mathrm{mmol})$ in THF $(12 \mathrm{ml}), i-\mathrm{PrOH}(4 \mathrm{ml})$ and water $(3 \mathrm{ml})$ was treated dropwise with a solution of $\mathrm{NaOH}(0.12$ $\mathrm{g}, 3.00 \mathrm{mmol})$ in water $(3 \mathrm{ml})$ within $2 \mathrm{~h}$. Stirring was continued for $2 \mathrm{~h}$ followed by evaporation of the solvent. Then water (20 $\mathrm{ml})$ and concentrated $\mathrm{HCl}(0.25 \mathrm{ml})$ were added to the reaction mixture and 2,4,5-trihexyl pyromellitate and unreacted tetrahexyl pyromellitate were extracted with $\mathrm{Et}_{2} \mathrm{O}$. After evaporation of the solvent the residue was chromatographed on $\mathrm{SiO}_{2}$ using chloroform for elution of unreacted tetrahexyl pyromellitate ( 0.64 $\mathrm{g})$ and acetone for elution of the product $(1.10 \mathrm{~g}, 94 \%)$. GC/MS:

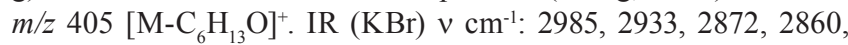
$1735,1717$.

Prepared 2,4,5-trialkyl pyromellitates were converted to the corresponding 4,5-bis(alkoxycarbonyl)phthalonitriles by procedures similar to published in ${ }^{[31]}$.

4,5-Bis(methoxycarbonyl)phthalonitrile. White solid with m.p. $128-130{ }^{\circ} \mathrm{C}$. Overall yield $37 \%$ (from anhydride 1). Anal. calcd. for $\mathrm{C}_{12} \mathrm{H}_{8} \mathrm{~N}_{2} \mathrm{O}_{4}$ : C 59.02, H 3.30, N 11.47. Found: C 59.13, $\mathrm{H}$ 3.21, N, 11.69. GC/MS: $m / z 245[\mathrm{M}+\mathrm{H}]^{+}$. IR $(\mathrm{KBr}) \vee \mathrm{cm}^{-1}: 3049$, 2959, 2240, 1732.

4,5-Bis(propyloxycarbonyl)phthalonitrile. White solid with m.p. $68-70{ }^{\circ} \mathrm{C}$. Overall yield $67 \%$ (from anhydride 1). Anal. calcd. for $\mathrm{C}_{16} \mathrm{H}_{16} \mathrm{~N}_{2} \mathrm{O}_{4}$ : C 63.99, H 5.37, N 9.33. Found: C 64.05, H 5.47, N 9.06. GC/MS: $m / z 301[\mathrm{M}+\mathrm{H}]^{+}$. IR (KBr) $v \mathrm{~cm}^{-1}: 3044,2972,2944$, 2883, 2243, 1731.

4,5-Bis(hexoxycarbonyl)phthalonitrile. White solid with m.p. $49-51{ }^{\circ} \mathrm{C}$. Overall yield $40 \%$ (from anhydride 1). Anal. calcd. for $\mathrm{C}_{22} \mathrm{H}_{28} \mathrm{~N}_{2} \mathrm{O}_{4}$ : C 68.73, H 7.34, N 7.29. Found: C 68.82, H 7.39, N 7.27. GC/MS: $m / z 385[\mathrm{M}+\mathrm{H}]^{+}$. IR (KBr) $v \mathrm{~cm}^{-1}: 3114,3051,2957$, 2924, 2871, 2854, 2239, 1721.

\section{Results and Discussion}

Previously ${ }^{[31]}$ we reported a method for preparation of 4,5-bis(ethoxycarbonyl)phthalonitrile by desymmetrization of pyromellitic anhydride $\mathbf{1}$. The key step in the synthesis 


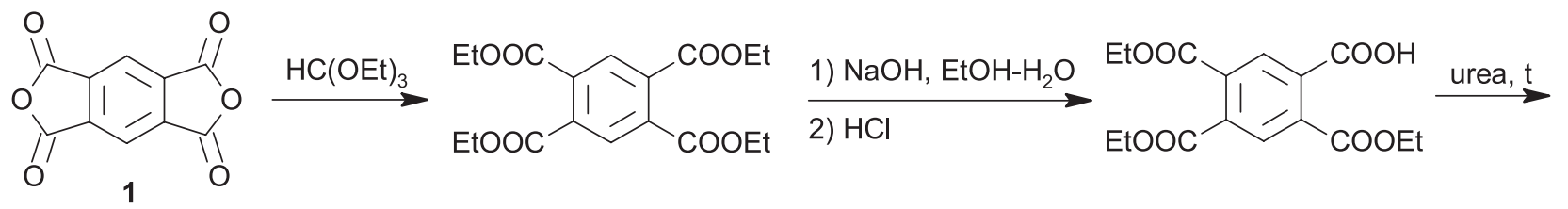<smiles>CCOC(=O)c1cc(C(N)=O)c(C(N)=O)cc1C(=O)OCC</smiles>

Scheme 1. Synthetic route to 4,5-bis(ethoxycarbonyl)phthalonitrile. ${ }^{[31]}$

1) urea, $t$

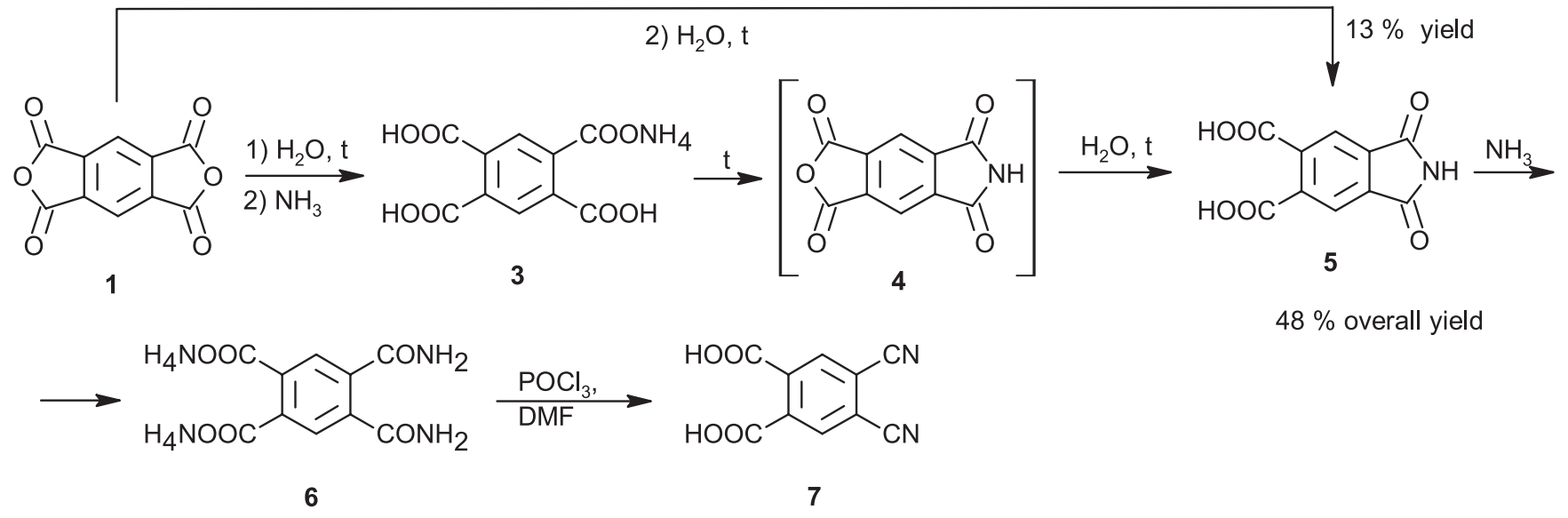

Scheme 2. Synthesis of 4,5-dicyanophthalic acid 7.

was the partial hydrolysis of tetraethyl pyromellitate to monoacid in aqueous ethanol ${ }^{[35]}$ (Scheme 1).

In next step the monoacid was fused with urea to form 4,5-bis(ethoxycarbonyl)phthalimide, followed by treatment with aqueous ammonia to give corresponding phthalamide, which was dehydrated with phosphorus oxychloride in DMF to give 4,5-bis(ethoxycarbonyl)phthalonitrile with high yield. 4,5-Bis(ethoxycarbonyl)phthalonitrile was used for synthesis of $\mathrm{OCPcM}$ and $\mathrm{OCPcH}_{2} \cdot{ }^{[31]}$

We attempted to apply this method for synthesis of 4,5bis(alkoxycarbonyl)phthalonitriles with other alkyl radicals (Me, Pr, Hx). Unfortunately, the partial trans-esterification occurred during the hydrolysis of tetraalkyl pyromellitates in aqueous ethanol at the second step with formation of mixture of esters. To avoid this process we had to find the specific solvent system for each alkyl case depending on the solubility of starting tetraalkyl pyromellitates which was a significant drawback of the method. Target 4,5-bis(alkoxycarbonyl)phthalonitriles were obtained from prepared 2,4,5-trialkyl pyromellitates by procedures similar to published in reference ${ }^{[31]}$ with moderate to good yields $(37,67,40 \%$ for $\mathrm{Me}, \mathrm{Pr}, \mathrm{Hx}$ radicals starting from anhydride 1).

We also tried to obtain other derivatives of 4,5-dicyanophthalic acid in a similar manner, for example, its $N$-alkyl imides. We synthesized asymmetrical mono- $N$-alkyl pyromellitic diimide, but the disclosure of the imide ring with aqueous ammonia was not selective and the mixture of products formed. Thus, the earlier developed synthetic route to 4,5-dicyanophthalic acid functional derivatives turned out to be not universal.

4,5-Dicyanophthalic acid 7 itself could be a convenient starting material for the preparation of its functional derivatives, but its synthesis has not been described yet. So, we focused on developing a simple method for preparation of acid 7 (Scheme 2).

Pyromellitic acid 2, prepared by hydrolysis of anhydride 1, was used as a starting material. We synthesized its asymmetrical derivative - 4,5-dicarboxyphthalimide 5, which was then converted to diamide $\mathbf{6}$ and further to acid 7 by standard procedures for preparation of substituted phthalonitriles.

First we tried to obtain imide 5 by reaction of anhydride 1 with excess of urea at high temperature. When it was heated with urea at 1:1 molar ratio, the main reaction product appeared to be pyromellitic diimide, along with the unreacted acid $\mathbf{2}$ and only traces of target monoimide $\mathbf{5}$. By decreasing the amount of urea (1:0.5 molar ratios) we managed to isolate monoimide 5 but it was formed with low yield (13\%).

Presumably, the amount of urea used in the synthesis was not sufficient for melting (and hence homogenization) of the reaction mixture. To solve this problem we obtained the monoammonium salt 3 by titration of aqueous solution of acid 2 with stoichiometric amount of ammonium hydroxide (1:1 molar ratio). After evaporation of the solvent, solid salt 
3 was heated for one hour at $260-270{ }^{\circ} \mathrm{C}$ to form imide 4 along with dianhydride $\mathbf{1}$ (formed from unreacted acid $\mathbf{2}$ ) and diimide by-product. The treatment of reaction mixture with hot water resulted in hydrolysis of imide $\mathbf{4}$ and dianhydride $\mathbf{1}$ to corresponding acids $\mathbf{5}$ and $\mathbf{2}$ followed by filtration to remove the insoluble diimide. Monoimide $\mathbf{5}$ precipitated from the filtrate on cooling with the yield of $46 \%$ unlike to acid 2 remaining in the solution.

To improve the yield of 4,5-dicarboxyphthalimide $\mathbf{5}$ we optimized molar ratio of the starting compounds (Table 1). Increasing the molar ratio of ammonium hydroxide from $1: 0.8$ to $1: 1.3$ did not influence markedly on the yield of monoimide 5 , but at the same time dramatically increased the yield of diimide. So, optimal molar ratio is found to be 1:0.8 (entry 1) because in this case more unreacted pyromellitic acid $\mathbf{2}$ can be isolated from the reaction mixture and used for further syntheses.

Table 1. Optimization of the reaction conditions for preparation of 4,5-dicarboxyphthalimide $\mathbf{5}$ from pyromellitic acid $\mathbf{2}$.

\begin{tabular}{cccc}
\hline Entry & $\begin{array}{c}\text { Pyromellitic acid } \\
\text { 2/ ammonia molar } \\
\text { ratio }\end{array}$ & $\begin{array}{c}\text { Yield of } \\
\text { monoimide } \\
\mathbf{5 , \%}\end{array}$ & $\begin{array}{c}\text { Yield of } \\
\text { diimide, \% }\end{array}$ \\
\hline 1 & $1: 0.8$ & 48 & 13 \\
2 & $1: 1$ & 46 & 26 \\
3 & $1: 1.3$ & 51 & 39 \\
\hline
\end{tabular}

The imide ring of monoimide $\mathbf{5}$ was opened by treatment with $25 \%$ aqueous ammonia. Then ammonia was evaporated in vacuum at room temperature and the ammonium salt of 4,5-dicarbamoylphthalic acid 6 was precipitated from water with acetone followed by dehydration with excess of phosphorus oxychloride in DMF. 4,5-Dicyanophthalic acid 7 was isolated as 1:1 solvate with DMF, which structure was confirmed by elemental analysis, IR, ${ }^{1} \mathrm{H}$ NMR spectroscopy.

With acid 7 in hands we obtained number of its functional derivatives - esters, diamides and imides - by standard procedures (Scheme 3).

Dimethyl or diethyl esters can be prepared by reaction of acid 7 with the corresponding commercially available trialkyl orthoformates by procedure similar to described in ${ }^{[35]}$. Esters with longer alkyl radicals can be obtained by reaction of acid 7 with alcohols in the presence of $N, N^{\prime}$-dicyclohexylcarbodiimide in dichloromethane or acetonitrile. For example, 4,5-bis(heptyloxycarbonyl)phthalonitrile $\mathbf{1 5}$ was synthesized with good yield by this method. We failed to obtain tert-butyl ester $\mathbf{1 6}$ by reaction of acid 7 with tert-butyl alcohol in the presence of $N, N$ '-dicyclohexylcarbodiimide most likely due to steric hindrances.

The reaction of 4,5-dicyanophthalic acid 7 with oxalyl chloride in dichloromethane leads to formation of 4,5-dicyanophthalic acid chloroanhydride $\mathbf{9}$, which readily reacts with alcohols in the presence of tertiary amine as a base to form corresponding esters. By this method esters of 4,5-dicyanophthalic acid with 2-dimethylaminoethanol 17 and highly sterically hindered tert-butyl alcohol 16 were obtained.

A series of 4,5-dicyanophthalic acid diamides 1114 were prepared by reaction of chloroanhydride 9 with secondary amines (diethylamine, dibutylamine, piperidine and 1-methylpiperazine) with good to moderate yields.

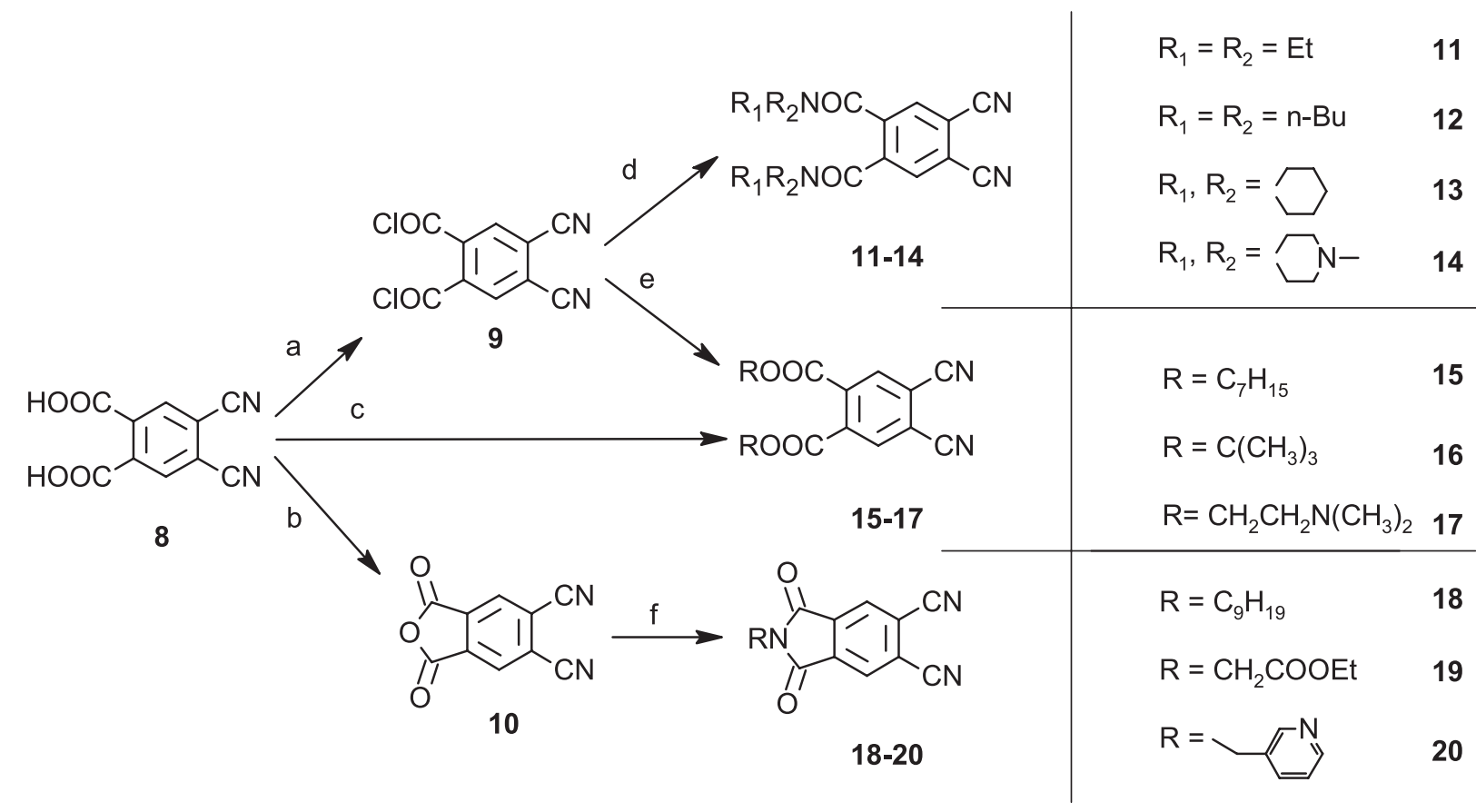

Reagents and conditions: (a) $(\mathrm{COCl})_{2}$, DCM, r.t.; (b) $\mathrm{AcCl}$, reflux; (c) $\mathrm{H}(\mathrm{COR})_{3}$, reflux $(\mathrm{R}=\mathrm{Me}$, Et) or $\mathrm{ROH}$, $N, N^{\prime}$-dicyclohexylcarbodiimide, DMAP, DCM or acetonitrile, r.t.; (d) $\mathrm{HNR}_{1} \mathrm{R}_{2}$, DCM, r.t.; (e) $\mathrm{ROH}$, $\mathrm{Et}_{3} \mathrm{~N}$ or pyridine, DCM, r.t.; (f) $\mathrm{H}_{2} \mathrm{NR}$, pyridine, $\mathrm{AcOH}$, reflux. 
Imides 18-20 are easily formed by reaction of anhydride 10, obtained in high yield by refluxing acid 7 with acetyl chloride, with primary amines in glacial acetic acid in the presence of catalytic amounts of a tertiary amine.

In this paper we focused our attention on preparation of phthalogens but we also would like to discuss briefly preparation of phthalocyanine compounds from synthesized phthalonitriles. Unfortunately, our attempts to obtain $\mathrm{OCPcM}$ or $\mathrm{OCPcH}_{2}$ directly from 4,5-dicyanophthalic acid 7 by commonly used procedures were not successful - the complexes formed in trace amounts or did not form at all.

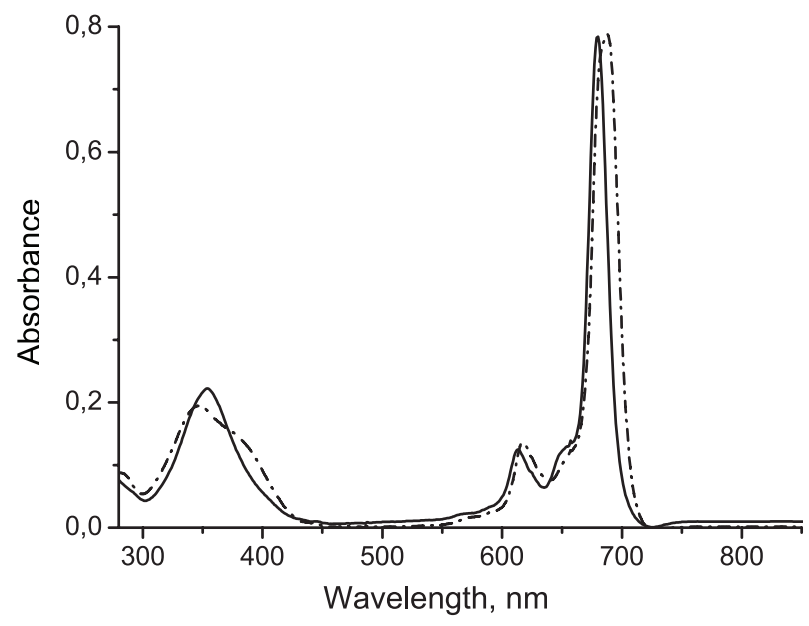

Figure 2. The electronic absorption spectra of compounds $\mathbf{2 1}$ (solid line) and 22 (dash-dot line) in DCM with $0.04 \% \mathrm{Et}_{3} \mathrm{~N}$.

Metal complexes from dinitriles 11-20 can be prepared by solvent free synthesis or by using such solvent as diglyme in the presence of DBU (see representative procedures in experimental section). One of the most commonly used methods for preparation of Pc - tetramerization of phthalonitriles in alcohol in the presence of DBU - cannot be used in this case due to the side reaction with the solvent, resulting in the mixture of products. We obtained zinc complexes from 4,5-bis(ethoxycarbonyl)phthalonitrile, phthalonitriles $\mathbf{1 1}$ and $\mathbf{1 8}$ in hexanol in the presence of DBU for 4 hours. The yields of all products were good, but the nitrogen content was lower than expected according to elemental analysis - evidently because of the side-reaction with hexanol. When zinc complex was prepared from 4,5bis(ethoxycarbonyl)phthalonitrile in hexanol in the presence of DBU for 24 hours the elemental analysis data were very close to the calculated values for the fully trans-esterificated product.

\section{Conclusions}

The methods for preparation of new phthalogens 4,5-dicyanophthalic acid and a number of its functional derivatives - were developed.

Acknowledgements. The authors are grateful to Dr. Negrimovsky V.M. for his help and useful advices and Belov A.V. for his valuable help.

\section{References}

1. Kaliya O.L., Lukyanets E.A. J. Porphyrins Phthalocyanines 1999, 3, 592-610.

2. Sorokin A.B. Chem. Rev. 2013, 113, 8152-8191.

3. Leznoff C.C., Lever A.B.P. Phthalocyanines: Properties and Applications, Volume 4, VCH, Weinheim, 1996.

4. Walter M.G., Rudine A.B. J. Porphyrins Phthalocyanines 2010, 14, 759-792.

5. Gonzalez-Rodriguez D., Bottari G. J. Porphyrins Phthalocyanines 2009, 13, 624-636.

6. Ali H., van Lier J.E. Porphyrins and Phthalocyanines as Photosensitizers and Radiosensitizers. In: Handbook of Porphyrin Science. 2011, Vol. 4, 1-119.

7. Lukyanets E.A. Photodynamic Therapy and Photodiagnosis 2013, 13(3), 3-16 (in Russ.).

8. Dumoulin F., Durmus M., Ahsen V., Nyokong T. Coord. Chem. Rev. 2010, 254, 2792-2847.

9. Shaposhnikov G.P., Kulinich V.P., Maizlish V.E. Modified Phthalocyanines and Their Structural Analogues. Moscow: Krasand, 2013. 480 p (in Russ.) [Шапошников Г.П, Кулинич В.П., Майзлиш В.Е. Модифициированные фталоциианины и их структурные аналоги. М.: Красанд, 2013. 480 с.]

10. Kobayashi N., Ohya T., Sato M., Nakajima Sh. Inorg. Chem. 1993, 32, 1803-1808.

11. Sergeyev S., Debever O., Pouzet E., Geerts Y. H. J. Mater Chem. 2007, 17, 3002-3007.

12. Lukyanets E.A., Nemykin V.N. J. Porphyrins Phthalocyanines 2010, 14, 1-40.

13. Cid J.-J., Garcia-Iglesias M., Yum J.-H., Forneli A., Albero J., Martinez-Ferrero E., Vazquez P., Gratzel M., Nazeeruddin M.K., Palomares E., Torres T. Chem. Eur. J. 2009, 15, 51305137.

14. García-Iglesias M., Yum J., Humphry-Baker R., Zakeeruddin S.M., Péchy P., Vázquez P., Palomares E., Grätzel M., Nazeeruddin M.K., Torres T. Chem. Sci. 2011, 2, 1145-1150.

15. Vorozhtsov G.N., Kazachkina N.I., Luzhkov Yu.M., Lukyanets E.A., Mikhalenko S.A., Solovyova L.I., Chissov V.I., Yakubovskaya R.I. Patent RF 2193 563, 2002.

16. Kuznetsova N.A., Gretsova N.S., Derkacheva V.M., Mikhalenko S.A., Solovyova L.I., Yuzhakova O.A., Kaliya O.L., Lukyanets E.A. Russ. J. Gen. Chem. 2002, 72, 300-306.

17. Syrkin A.B., Zhukova O.S., Kikot' B.S., Gatinskaya L.G., Treshchalina E.M., Yakubovskaya R.I., Pankratov A.A., Mikhailova L.M., Zimakova N.I., Kolesnikova E.Yu., Oborotova N.A., Polozkova A.P., Gerasimova G.K., Kaliya O.L., Kuz'min S.G., Lukyanets E.A., Vorozhtsov G.N., Trapeznikov N.N. Ross. Khim. Zh. 1998, 42(5), 140-146 (in Russ.).

18. Gerasimova G.K., Yakubovskaya R.I., Pankratov A.A., Treshchalina E.M. et al. Ross. Khim. Zh. 2013, 57(2), 69-82 (in Russ.).

19. Andronova N.V., Filonenko D.V., Nikolaev A.L., Gopin A.V., Treshchalina E.M., Kaliya O.L., Vorozhtsov G.N. Ross Bioterap. Zh. 2009, 2, 3 (in Russ.).

20. Andronova N.V., Bozhevolnov V.E., Gopin A.V., Vorozhtsov G.N., Kaliya O.L., Lukyanets E.A., Melikhov I.V., Nikolaev A.L., Solovyova L.I., Treshchalina E.M., Filonenko D.V. Patent RF 2375090, 2009.

21. Dolotova O.V., Kaliya O.L. Russ. J. Coord. Chem. 2007, 33, 111-115.

22. a) Dolotova O., Kaliya O.L. J. Porphyrins Phthalocyanines 2011, 15, 632-638; b) Bulgakov R.A., Kuznetsova N.A., Dolotova O.V., Shevchenko E.N., Plyutinskaya A.D., Kaliya O.L., Nyokong T. Macroheterocycles 2012, 5, 350-357 (in Russ.).

23. Malinga N., Dolotova O., Bulgakov R., Antunes E., Nyokong T. Dyes Pigm. 2012, 95, 572-573. 
24. Wöhrle D., Preußner E. Makromol. Chem. 1985, 186, 21892207.

25. Boston D.R., Bailar J. C. Inorg. Chem. 1972, 11, 1578-1582.

26. Wöhrle D., Meyer G., Wahl B. Makromol. Chem. 1980, 181, 2127-2135.

27. Suchan A., Hurek J., Waclawek W., Nackiewicz J., Ejsmont K. Polish J. Chem. 1999, 73, 2013-2025.

28. Opris D.M., Nüesch F., Löwe C., Molberg M., Nagel M. Chem. Mater. 2008, 20, 6889-6896.

29. Tylleman B., Gomez-Aspe R., Gbabode G., Geerts Y.H., Sergeyev S. Tetrahedron 2008, 64, 4155-4161.
30. Wang X., Zhang Y., Sun X., Bian Y., Ma C., Jiang J. Inorg. Chem. 2007, 46, 7136-7141.

31. Kuznetsova N.A., Shevchenko E.N., Makarov D.A., Slivka L.K., Solovyova L.I., Kaliya O.L., Lukyanets E.A. J. Porphyrins Phthalocyanines 2012, 16, 1244-1251.

32. Freccero M., Fasani E., Albini A. J. Org. Chem. 1993, 58, 1740-1745.

33. Solovyova L.I., Lukyanets E.A. Zh. Obshch. Khim. 1980, 50(5), 1122-1131 (in Russ.).

34. Solovyova L.I., Lukyanets E.A. Russ. J. Gen. Chem. 2004, 74(3), 451-459.

35. Paine J.B. III. J. Org. Chem. 2008, 73, 4929-4938.

Received 15.05.2014

Accepted 02.06.2014 